\title{
Phytochemical Screening and Antibacterial Activity of Grape Seed Extract
}

\author{
J. Siva Jyothi ${ }^{* 1}$, S. Bhavya sri ${ }^{2}$, T. Hasan shaik ${ }^{2}$, Y.Samson ${ }^{2}$, P. Jawahar Babu ${ }^{3}$ \\ ${ }^{1}$ Assistant Professor, Department of Pharmaceutical Biotechnology, Hindu College of Pharmacy, Amaravathi Road, \\ Guntur-522002, A.P., India. \\ 2, 3 Hindu College of Pharmacy, Amaravathi Road, Guntur-522002, A.P., India.
}

*Corresponding author's E-mail: jsjbiotech81@gmail.com

Received: 10-09-2021; Revised: 16-11-2021; Accepted: 23-11-2021; Published on: 20-12-2021.

ABSTRACT

In the present investigation, preliminary phytochemical screening and antibacterial activity of diethyl ether, methanol and aqueous Grape seed extracts were examined. The phytochemical analysis revealed the presence of active ingredients such as flavonoids, phenols, terpenoids, saponins in Grape seed extracts. The antibacterial activity was performed by agar-well diffusion method using different solvent extracts. Three bacterial pathogens such as gram positive- Streptococcus pyogenes and gram negativePectobacterium carotovorum, Pseudomonas putida were used as test organisms. Among the three solvents used methanolic extract was found to be more active against tested pathogenic bacteria, as they showed potential phytochemical constituents. Among all the tested organisms Streptococcus pyogenes was found to be more sensitive by all the extracts. The results of present study supports the usage of Grape seeds and also suggests that methanolic grape seed extract possess compounds with antimicrobial property that can be used as antimicrobial agent for the therapy of infectious diseases caused by pathogens.

Keywords: Grape seed extract, Phytochemical screening, Antibacterial activity, Agar-well diffusion method.

QUICK RESPONSE CODE $\rightarrow$

DOI:

10.47583/ijpsrr.2021.v71i02.003

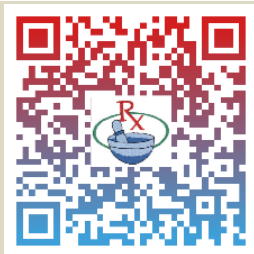

DOI link: http://dx.doi.org/10.47583/ijpsrr.2021.v71i02.003

\section{INTRODUCTION}

P lants play a major role in traditional medicine system for health care. The abundance of plants on the earth's surfaces has led to the growing interest in correlating phytochemical constituents of a plant with its pharmacological activity. ${ }^{1}$ Plants have been considered as rich sources of natural phytochemicals which are having more biological activities. Grapes, one of the most popular fruits and the most widely cultivated crop throughout the world, contain large amounts of phytochemicals including anthocyanins and resveratrol, which offer health benefits. ${ }^{2}$ Grapes are one of the major dietary sources of anthocyanins, which are responsible for the colouring of black, red and purple grapes; however, they are lacking in white grapes.

The bioactive compounds present in plants like alkaloids, flavonoids, tannins and phenolic compounds are the reason for their medicinal value that produce a definite physiological action on the body. ${ }^{3}$ Now a day's people are using natural phytochemicals instead of synthetic drugs. Herbal medicines have received much attention as sources of lead compounds since they are considered as time tested and relatively safe for both human use and environment friendly.$^{4,5}$ They are cheap, easily available and also affordable. Antibiotics shows some side effects like allergic reactions, disturbances of normal flora of intestine. Therefore, there is a need to develop alternative antimicrobial drugs for the treatment of infectious diseases.

Plant diseases are controlled by different fungicides and bactericides, which have vast utilization in the field of agriculture. It has been a subject of public concern due to the harmful effects on the ecosystem and their carcinogenic quality. Hence bioactive compounds from plant extracts can be an alternative against pathogens. The beneficial health-related effects of phenolics in grapes are of important to consumers, breeders and the grape industry. Keeping this in view, an attempt was made to explore its phytoconstituents and to determine the potential antibacterial activity of Grape Seed Extracts.

\section{MATERIALS AND METHODS}

\section{Preparation of Grape Seed Extract (GSE)}

Fully ripened black grapes were purchased from a local shop in market of Guntur city. The seeds were separated from the grapes by crushing. The separated seeds were washed with distilled water and dried in an oven at $60^{\circ} \mathrm{C}$. Dried seeds were powdered using a blender. 25g of accurately weighed grape seed powder was treated with $100 \mathrm{ml}$ of diethylether, methanol and aqueous solvents in a conical flask and stirred well. The flasks were left aside for 48 hours and occasionally stirred. Filter the contents of flask through Whatman No. 1 and evaporated to dryness at $50^{\circ} \mathrm{C}$ in an oven. ${ }^{6}$

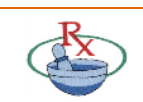




\section{Phytochemical Screening ${ }^{7}$}

Diethyl ether, Methanol and aqueous Grape seed extract (GSE) extracts were subjected to qualitative chemical tests to identify the nature of the phytoconstituents i.e. flavonoids, alkaloids, glycosides, steroids, saponins, terpenoids and tannins.

\section{Test for alkaloids (Mayer's test)}

A small amount of all Grape seed extract (GSE) extracts were neutralized by adding 1 or 2 drops of dilute $\mathrm{H}_{2} \mathrm{SO}_{4}$. The resulting solution was treated with a small amount of Mayer's reagent. Appearance of white precipitate confirms the presence of alkaloids.

\section{Test for flavonoids (Shinoda test)}

A few drops of concentrated Hydrochloric acid and 1 or 2 magnesium turnings were added to $1 \mathrm{ml}$ of extracts. The presence of flavonoids was indicated by the development of pink or magenta red colour.

\section{Test for anthocyanins (Sodium hydroxide test)}

$1 \mathrm{ml}$ of $2 \mathrm{~N} \mathrm{NaOH}$ was added to $2 \mathrm{ml}$ of extract and heated for 5 minutes at $100^{\circ} \mathrm{C}$. Bluish green colour formation indicates the presence of anthocyanin.

\section{Test for anthraquinones (Borntrager's test)}

2-3 drops of dilute $\mathrm{HCl}$ was added to the extract and the mixture was boiled for 2 minutes (hydrolysis of glycosides). Then the mixture was filtered and cooled. The filtrate was separated and shaken vigorously with $10 \%$ ammonium hydroxide. Immediate appearance of rose pink or cherry red color in aqueous layer confirms the presence of anthraquinones.

\section{Test for saponins}

$5 \mathrm{ml}$ of distilled water was added to $5 \mathrm{ml}$ of extract and shaken for the formation of froth which indicates the presence of saponins.

\section{Test for steroids and terpenoids}

A small portion of extract was dissolved in $1 \mathrm{ml}$ of chloroform and filtered. Kept the filtrate on ice, $1 \mathrm{ml}$ of acetic acid was added to the filtrate and then a few drops of concentrated $\mathrm{H}_{2} \mathrm{SO}_{4}$ were run down the side of the test tube. Appearance of blue, bluish-green or a rapid change from pink to blue colours indicates the presence of steroids, the appearance of pink or pinkish-brown ring/color indicates the presence of terpenoids and a combination of both colours indicates the presence of both steroids and terpenoids.

\section{Test for carbohydrates (Fehling's test)}

Equal quantities of Fehling's solution A and B were added to the extracts and upon heating; formation of a brick red precipitate indicates the presence of carbohydrates.

\section{Test for glycosides (Borntrager's test)}

2-3 drops of concentrated $\mathrm{HCl}$ was added to the extract. Then the mixture was boiled for 2 minutes (hydrolysis of glycosides). Then the mixture was filtered and cooled. The filtrate was extracted with chloroform. The chloroform layer was separated and shaken vigorously with $10 \%$ ammonium hydroxide. Appearance of pink color in aqueous layer confirms the presence of glycosides.

\section{Test for phenol compound (Lead acetate test)}

The extract was dissolved in $5 \mathrm{ml}$ of distilled water. To this, $3 \mathrm{ml}$ of $10 \%$ lead acetate was added. Appearance of white precipitate indicates the presence of phenols.

\section{Test for protein and amino acids (Biuret test)}

The extract $(100 \mathrm{mg})$ was dissolved in $10 \mathrm{ml}$ of distilled water and filtered though whatmann no.1 filter paper and further an aliquot of filtrate was treated with one drop of $2 \% \mathrm{CuSO}_{4}$ solution. To this solution, $1 \mathrm{ml}$ of ethanol (95\%) and excess of sodium hydroxide pellets were added. Pink color in the ethanolic layer indicates the presence of proteins and amino acids.

\section{Antibacterial activity of GSE ${ }^{6}$}

Agar well diffusion method was used to investigate antibacterial activity of Grape seed extracts against three pathogenic bacteria viz., Pectobacterium carotovorum (MTCC 1428), Streptococcus pyogenes (MTCC 1924) and Pesudomonas putida (MTCC 2467). 24 hours old Nutrient broth (Hi Media)) cultures of test bacteria were swabbed uniformly on sterile Nutrient agar (Hi Media) plates. Using sterile cork borer, wells of $8 \mathrm{~mm}$ diameter were prepared in the inoculated plates. $30 \mu \mathrm{l}$ of $1 \mathrm{mg} / \mathrm{ml}$ of GSE in dimethyl sulfoxide, standard antibiotic (Streptomycin, $10 \mu \mathrm{g} / \mathrm{ml}$ ), were added to labeled wells and the plates were incubated for 24 hours at $37^{\circ} \mathrm{C}$. The zones of inhibition around the wells were measured in millimeters using antibiotic zone reader. Each assay in this experiment was repeated for three times.

\section{RESULTS}

\section{Phytochemical screening}

In the present study, the phytochemical screening was studied with diethyl ether, Methanol and aqueous Grape seed extracts (GSE). The results revealed that diethyl ether, Methanol and aqueous Grape seed extracts (GSE) were rich in saponins, flavonoids, phenols, terpenoids. Steroids and Glycosides are absent in diethyl ether and Methanolic extracts. Results of the phytochemical screening studies for diethyl ether, methanolic and aqueous Grape seed extracts (GSE) were presented in table 1. 
Table. 1: Preliminary Phytochemical screening of Grape seeds Extract (GSE)

\begin{tabular}{|c|c|c|c|c|}
\hline S. & Chemical test & \multicolumn{4}{|c|}{ Grape seed Extract } \\
\hline No. & ether & Methanolic & Aqueous \\
\hline 1. & Alkaloids & + & + & + \\
\hline 2. & Flavonoids & + & + & + \\
\hline 3. & Anthocyanins & + & + & + \\
\hline 4. & Anthraquinones & + & + & + \\
\hline 5. & Saponins & + & + & + \\
\hline 6. & Steroids & - & - & - \\
\hline 7. & Terpenoids & + & + & + \\
\hline 8. & Carbohydrates & + & + & + \\
\hline 9. & Glycosides & - & - & + \\
\hline 10. & Phenols & + & + & + \\
\hline 11. & Proteins & + & + & + \\
\hline & + & Indicates the present, - Indicates the absent \\
\hline
\end{tabular}

\section{Antibacterial activity}

The antibacterial activity of different concentrations of diethyl ether, Methanol and aqueous extracts of the Grape seed extracts against pathogenic bacteria were presented in Table 2. The mean zone of inhibition for diethyl ether Grape seed extract ranging from 6.2 to $9.1 \mathrm{~mm}$. The mean zone of inhibition for Methanolic Grape seed extract ranging from 12.2 to $18.3 \mathrm{~mm}$. The mean zone of inhibition for aqueous Grape seed extract ranging from 9.5 to 11.6 $\mathrm{mm}$.

\section{DISCUSSION}

\section{Photochemical screening}

Phytochemical constituents such as Phenols, flavonoids and several other aromatic compounds or secondary metabolites of plants serve as defense mechanism against many microorganisms.

The curative properties of medicinal plants are perhaps due to the presence of various secondary metabolites such as flavonoids, phenols, saponins etc. The presence of saponins, flavonoids, phenols and terpenoids in the seed extract are very important and are used in analgesic, antiinflammatory and bactericidal activities. Thus the preliminary screening test may be useful for the detection of the bioactive principles and may lead to the drug discovery and development.

Table 2: Antibacterial activity of Grape Seed extracts against test bacteria

\begin{tabular}{|c|c|c|c|c|c|c|}
\hline \multirow{2}{*}{ Test Bacteria } & \multicolumn{5}{|c|}{ Mean Zone of inhibition $(\mathbf{m m}){ }^{\text {a }}$} \\
& Control & $\begin{array}{c}\text { Standard antibiotic } \\
\text { (Streptomycin) }\end{array}$ & $\begin{array}{c}\text { Diethyl ether } \\
\text { GSE }\end{array}$ & $\begin{array}{c}\text { Methanolic } \\
\text { GSE }\end{array}$ & $\begin{array}{c}\text { Aqueous } \\
\text { GSE }\end{array}$ \\
\hline $\begin{array}{c}\text { Pectobacterium carotovorum } \\
\text { Streptococcus pyogenes }\end{array}$ & $0.0 \pm 0.0$ & $19.2 \pm 0.53$ & $10.1 \pm 0.34$ & $14.2 \pm 0.35$ & $8.5 \pm 0.45$ \\
\hline Pseudomonas putida & $0.0 \pm 0.0$ & $22.4 \pm 0.58$ & $11.6 \pm 0.62$ & $18.3 \pm 0.23$ & $9.1 \pm 0.54$ \\
\hline a- mean of three assays; & $0.0 \pm 0.0$ & $17.6 \pm 0.65$ & $9.5 \pm 0.61$ & $12.2 \pm 0.38$ & $6.2 \pm 0.71$ \\
\hline
\end{tabular}

\section{Antibacterial activity}

The evaluation of antibacterial activity by agar-well diffusion method indicated that all the tested organisms showed growth inhibition towards the Grape seed extract, with differing sensitivity. Among the bacterial pathogens, Streptococcus pyogenes is more sensitive when compared to other bacteria. Gram-positive bacteria were exhibited more sensitiveness to Grape seed extracts when compared to Gram-negative bacteria.

The different solvents viz, diethyl ether, methanol and aqueous of Grape seed extracts were tested for antibacterial activity. All the test pathogens were highly sensitive to methanolic extract followed by diethyl ether and aqueous extracts.

\section{CONCLUSION}

As the search for new antimicrobial agents is in demand, plant extracts may provide attractive alternate sources of antimicrobial drug against various microbial diseases. The utilization of grape seeds is advantageous in terms of waste reduction and production of added value products. In the present study, the methanolic Grape seed extract was found to exhibit marked antibacterial activity.

\section{REFERENCES}

1. Gupta SS, Prospects and Perspectives of Natural Plant Products in Medicine, Indian Journal of Pharmacology, 1994; 26(1): 1-12.

2. Pezzuto JM, Grapes and human health: A perspective, Journal of Agricultural and Food Chemistry, 2008; 56(16): 6777-6784.

3. Hemashenpagam N, Growther Lali, Sankar, Selvaraj T and Panneerselvam A, Photochemical Analysis and Antimicrobial Activity Of Solanum xanthocarpum, Biomedicine, 2009; 29 (4): 353-356.

4. Suhaj $M$, Spice antioxidants isolation and their antiradical activity: a review, Journal of Food composition and Analysis, 2006; 19: 513-37.

5. Fazly-Bazzaz BS, Khajehkaramadin M, Shokooheizadeh $\mathrm{HR}$, In-vitro antibacterial activity of Rheum ribes extract obtained from various plant parts against clinical 
isolates of Gram-negative pathogens, Iranian J Pharm Res, 2005; 4(2): 87-91.

6. Manasa M, Vivek MN, Kambar Y, Kumar RKA, Kekuda PTR, Mineral content, antimicrobial and radical scavenging potential of Caesalpinia mimosoides (Caesalpiniaceae), World Journal of Pharmaceutical Research, 2014; 3(4): 1047-1063.

7. Kokate CK, Purohit AP, Gokhale SB,Pharmacognosy (Text book), 2009; Appendices: A.1-A.5.

8. Georgiev V, Ananga A, Tsolova V, Recent advances and uses of grape flavonoids as nutraceuticals, Nutrients, 2014; 6(1): 391-415.

9. 9. Lin JK, Weng MS, Flavonoids as nutraceuticals, in The Science of Flavonoids, E. Grotewold, Ed., Springer, Berlin, Germany, 2006;213-238.

10. Le Marchand L, Cancer preventive effects of flavonoidsa review, Biomedicine and Pharmacotherapy, 2002; 56(6): 296-301.

11. $\mathrm{Wu} C D$, Grape products and oral health, Journal of Nutrition, 2009; 139(9): 1818S-1823S.

12. Kishore kumar K, Gnananath K, Sujatha S, Aswani B, Siva Jyothi J, Phytochemical screening, formulation and evaluation of wound healing activity of root extract of Eriolaena hookeriana wt.arn. ointment on rats, European Journal of Pharmaceutical and Medical Research, 2016;3(12): 229-234.

13. Dani C, Oliboni LS, Pra D, Mineral content is related to antioxidant and antimutagenic properties of grape juice, Genetics and Molecular Research, 2012;11(3): 3154-3163.

14. Andreucci M, Faga $T$, Pisani $A$, Reversal of radiocontrast medium toxicity in human renal proximal tubular cells by white grape juice extract, Chemico-Biological Interactions, 2015; 229: 17-25.

15. Giacoppo S, Galuppo M, Lombardo GE, Neuroprotective effects of a polyphenolic white grape juice extract in a mouse model of experimental autoimmune encephalomyelitis, Fitoterapia,2015; 103: 171-186.

16. Mandalari G, Bisignano C, Arrigo MD, Antimicrobial potential of polyphenols extracted from almond skins, Letters in Applied Microbiology, 2010; 51(1): 8389.

17. Bisignano C, Filocamo A, Faulks RM, and Mandalari G, In vitro antimicrobial activity of pistachio (Pistacia vera L.) polyphenols, FEMS Microbiology Letters, 2013; 341(1): 62-67.

18. Mandalari G, Bennett RN, Bisignano G, Antimicrobial activity of flavonoids extracted from bergamot (Citrus bergamia) peel, a byproduct of the essential oil industry, Journal of Applied Microbiology, 2007; 103(6): 2056-2064.

19. Asha DS, Jolita AB, Ishii N, Grape seed proanthocyanidin extract (GSPE) and antioxidant defence in the brain of adult rats, Medical Science Monitor, 2006; 1294): 124-129.

20. Bhaskar S, Shalini V, Helen A, Quercetin regulates oxidized LDL induced inflammatory changes in human PBMCs by modulating the TLR-NF-KB signaling pathway, Immunobiology, 2011; 216(3): 367-373.

21. Chouinard JA, Grenier G, Khalil A, Vermette $P$, Oxidiz ed-LDL induce morphological changes and increase stiffness of endothelial cells, Experimental Cell Research, 2008; 314(16): 3007-3016.

Source of Support: The author(s) received no financial support for the research, authorship, and/or publication of this article.

Conflict of Interest: The author(s) declared no potential conflicts of interest with respect to the research, authorship, and/or publication of this article.

For any question relates to this article, please reach us at: editor@globalresearchonline.net New manuscripts for publication can be submitted at: submit@globalresearchonline.net and submit_ijpsrr@rediffmail.com 